\title{
Effects of grazing exclusion on carbon sequestration and plant diversity in grasslands of China-A meta-analysis
}

\author{
Dingpeng Xiong ${ }^{\mathrm{a}, \mathrm{b}}$, Peili Shi ${ }^{\mathrm{a}, *}$, Xianzhou Zhang ${ }^{\mathrm{a}}$, Chris B. Zou ${ }^{\mathrm{c}}$ \\ ${ }^{a}$ Lhasa National Ecological Research Station, Key Laboratory of Ecosystem Network Observation and Modeling, Institute of Geographic Sciences and \\ Natural Resources Research, Chinese Academy of Sciences, A11 Datun Road, Chaoyang District, Beijing 100101, PR China \\ b University of Chinese Academy of Sciences, NO. 19 Yuquan Road, Beijing 100049, PR China \\ ${ }^{c}$ Department of Natural Resource Ecology E' Management, Oklahoma State University, 562 Agricultural Hall, Stillwater, OK 74078, USA
}

\section{A R T I C L E I N F O}

\section{Article history:}

Received 9 August 2015

Received in revised form 27 June 2016

Accepted 27 June 2016

Available online 26 July 2016

\section{Keywords:}

Carbon stocks

Plant diversity

Grazing exclusion

Grasslands

Meta-analysis

\begin{abstract}
A B S T R A C T
Widespread land degradation has strengthened the urgent need to restore overgrazing grasslands. China has implemented the program 'Returning Grazing Land to Grassland' (RGLG) through grazing exclusion by fence since 2003. Despite a lot of field experiments, there is still controversy on the effects of grazing exclusion on rangeland restoration, highlighting the need for synthetic analysis. We conducted a metaanalysis of 447 entries from 78 papers to analyze the spatiotemporal effects of grazing exclusion on plant diversity, productivity and soil carbon sequestration in the major RGLG-implemented provinces of China. Our results showed that, compared with the grazed sites, grazing exclusion significantly increased carbon stored in aboveground biomass, litter mass, belowground biomass and soils by $84.7 \%, 111.6 \%, 25.5 \%$ and $14.4 \%$, respectively. Plant coverage, soil available nitrogen, soil available phosphorus and soil microbial biomass carbon increased by $52.0 \%, 21.7 \% 22.8 \%$ and $26.3 \%$, respectively. However, grazing exclusion had little effects on recovering plant diversity in China's grasslands. Of the factors examined, climatic factors strongly modified the effects of grazing exclusion on ecosystem carbon stocks, for example, precipitation significantly amplified the positive effects. Grazing exclusion played a positive role in soil carbon sequestration in most grassland types except in temperate desert-steppe. But annual soil carbon sequestration rates decayed rapidly over time in both alpine meadow and temperate steppe. Short-term ( $\leq 5$ years) grazing exclusion remarkably increased species richness, but not significantly in the long run. The threshold from neutral to negative effects of grazing exclusion on species evenness occurs after approximately ten years. Our findings provide evidence that grazing exclusion is an effective way to restore vegetation and sequestrate carbon in degraded grasslands, but not beneficial to plant diversity maintenance. The benefits of grazing exclusion are more effective in humid area than arid area. We suggest that grazing exclusion should be ceased after about six to ten years. Additionally, grazing exclusion should integrate with other appropriate management practices instead of operating on a stand-alone basis.
\end{abstract}

(c) 2016 Elsevier B.V. All rights reserved.

\section{Introduction}

Grasslands have an important feedback effect in global climate change (Scurlock and Hall, 1998; Lal, 2004), as they contain a large amount of carbon susceptible to anthropogenic disturbance (Anderson, 1991; Derner et al., 2006). Livestock grazing is a pivotal issue affecting plant growth, species diversity and soil carbon accumulation in grasslands (Olff and Ritchie, 1998; Watkinson and Ormerod, 2001; Piñeiro et al., 2010; McSherry and

\footnotetext{
* Corresponding author.

E-mail addresses: xiongdp.11b@igsnrr.ac.cn (D. Xiong), shipl@igsnrr.ac.cn (P.Shi), zhangxz@igsnrr.ac.cn (X. Zhang), chris.zou@okstate.edu (C.B.Zou).
}

Ritchie, 2013). Globally, excessive grazing is identified as one of the key disturbances leading to grasslands degradation and soil carbon loss (Snyman and du Preez, 2005; Akiyama and Kawamura, 2007; Papanastasis 2009; Jeddi and Chaieb, 2010). Widespread land degradation has strengthened the urgent need to restore overgrazing degraded grasslands in order to alleviate its negative effect and improve ecosystem goods and services.

Grazing exclusion by fence has become a common practice worldwide for managing overgrazed grasslands. The aim of grazing exclusion is to reverse the negative effects of overgrazing and recover degraded grasslands through their self-healing capacities (Smith et al., 2000; Shrestha and Stahl, 2008; Wu et al., 2009; Golodets et al., 2010). However, there is controversy in the effects of grazing exclusion on grassland carbon stocks and plant diver- 
sity. For carbon sequestration, some studies found that grazing exclusion facilitated vegetation recovery, increased plant productivity and thus enhance soil carbon stocks in degraded grasslands (Biondini et al., 1998; McIntosh and Allen, 1998; Li et al., 2008; Mekuria et al., 2007; Mekuria and Veldkamp, 2012; Xiong et al., 2014). Others, however, reported no change (McNaughton et al., 1998; Pucheta et al., 2004) or even decline of carbon stocks in grasslands (Schuman et al., 1999; Leriche et al., 2001; Frank et al., 2002; Wienhold et al., 2001). Controversial results have also been found on a regional and global scale. For example, Derner and Schuman (2007) synthesized data from the North American Great Plains and found that soil carbon stocks were lower in un-grazed than in grazed sites in areas with mean annual precipitation (MAP) of $600 \mathrm{~mm}$ or less. In contrast, in central Asia or Africa, many studies found positive effects of grazing exclusion on soil organic carbon (SOC) at sites with MAP less than $600 \mathrm{~mm}$ (Su et al., 2005; Wu et al., 2008; Mekuria et al., 2007; Mekuria and Veldkamp, 2012). For plant diversity, the results are also conflicting. Several studies reported no effects of grazing exclusion on plant diversity (Milchunas and Lauenroth, 1993; Meissner and Facelli, 1999), while a number of studies reported increases (Shaltout et al.,1996; Eweg et al., 1998; Shang et al., 2008; Mayer et al., 2009; Jeddi and Chaieb, 2010; Zhao et al., 2011), and others reported decreases (Proulx and Mazumder, 1998; Dullinger et al., 2003; Altesor et al., 2005; Peco et al., 2005, 2006; Wu et al., 2009), in plant diversity in response to grazing exclusion. Generally, the effectiveness of grazing exclusion denpends on its duration (Milchunas and Lauenroth, 1993; Su et al., 2005; Wu et al., 2008; McSherry and Ritchie, 2013), environmental conditions (Conant and Paustian, 2002; Derner and Schuman, 2007; Piñeiro et al., 2010; J.S. Wu et al., 2012, 2014) and vegetation types (Proulx and Mazumder, 1998; Tanentzap and Coomes, 2012; McSherry and Ritchie, 2013) in specific sites.

China's grasslands cover approximately $6-8 \%$ of the world's total area and contain $9-16 \%$ of the world's total grassland $\mathrm{C}$ stocks $(\mathrm{Ni}$, 2002), hence playing an important role in regional climate change and global C cycling (Ni, 2002; Piao et al., 2009). The stocking rates usually exceed the safe carrying capacity (Chen et al., 2003). Over $90 \%$ of rangelands have been widely degraded (Liu and Diamond, 2005; Han et al., 2008), owing to long-term overgrazing (Akiyama and Kawamura, 2007; X. Wu et al., 2014). In the last 20 years, fence has been widely used in China to restore degraded rangelands. Especially, the area of grazing exclusion has reached 26.2 million hectares, accounting for $10.8 \%$ of China's natural grasslands since national conservation program RGLG implemented in 2003 (MAO, $2007,2014)$. Despite numerous site-level studies have analyzed the effects of grazing exclusion on diversity and carbon sequestration, controversial results still exist (Ren et al., 2008; Wu et al., 2010; Cheng et al., 2011; Hafner et al., 2012). These inconsistent results constrain our ability to make management decisions based on the literature. Therefore, it is necessary to make a synthetic assessment on the effects of grazing exclusion for grassland restoration. The synthesis would be highly relevant for knowledge sharing and providing recommendation for rangeland management. However, to our knowledge, there has been little synthetic analysis assessing the overall effects of grazing exclusion at the regional or country level in China.

Meta-analysis provides a robust, quantitative synthetic method for a collection of studies (Hedges et al., 1985), and can identify generalities of impacts over the large variability (Gurevitch and Hedges, 1999). The use of meta-analysis is important to summarize the generalities and identify influencing factors. In order to ascertain how grazing exclusion influences carbon sequestration and plant diversity in China's degraded grasslands, we collected published data of pair-wise comparison with grazed vs. un-grazed studies for meta-analysis. Specifically, we aimed to: (1) quantify the magnitude and direction of the overall effects of grazing exclusion on ecosystem carbon stocks, including aboveground biomass, belowground biomass and soils; (2) examine the overall effects of grazing exclusion on different diversity indices, species richness, species evenness, the Shannon index and the Simpson index; (3) identify factors influencing the effects of grazing exclusion on carbon sequestration and plant diversity, and provide recommendations for sustainable grassland management practices.

\section{Materials and methods}

\subsection{Data compilation}

This study focuses on the major implemention region of the RGLG project in China, mainly the temperate grasslands in the northern region and alpine grasslands on the Qinghai-Tibetan Plateau. To collect data that quantifies the effects of grazing exclusion, we searched peer-reviewed journal articles published both in English and in Chinese using the ISI Web of Science and China National Knowledge Infrastructure (CNKI) (1999-2014). We used the following search term combinations: "Grazing" OR "grazing exclusion" OR "enclosure" OR "fencing" OR "fence” OR "grazing removal" OR "exclosure" OR "no grazing", and then refined with the keyword "China". We also considered further studies cited in these references; and studies published as dissertations. From more than 2000 articles containing these search terms; we selected those which met the following criteria:

1. Comparative field studies either observational (free grazing vs. grazing exclusion) or experimental (simulated grazing vs. grazing exclusion) conducted in natural grazed grasslands. Those studies carried out in virgin grasslands or artificial grasslands were excluded.

2. Studies that measured any of the following variables: aboveground biomass (AGB), belowground biomass (BGB), SOC stock, coverage, aboveground litter mass, plant diversity, soil available nitrogen (SAN) content, soil available phosphorus (SAP) content, and soil microbial biomass carbon (SMBC) content. For belowground $C$ stock, sampling depth information was essential.

3. Duration of grazing exclusion should be at least one year. When more than one articles published data from the same site, the latest publication with the most recent data was given priority.

4. There were no other practices (e.g. fertilization or seeding) conducted in the fenced sites.

5. The means, standard deviations or standard errors, and sample sizes of treatment and control were directly reported, or could otherwise be determined from the chosen articles.

We also collected potentially useful information from each publication, including coordinates, elevation, mean annual temperature (MAT), mean annual precipitation (MAP), duration of grazing exclusion, sampling soil depth and grassland type. If climatic information was not available in the original article, we used data from the nearest meteorological station instead. Data of biomass or $\mathrm{C}$ stock were extracted directly from tables or text in the original papers, or indirectly from figures using the DATATHIEF III software (B. Tummers, DataThief III. 2006 http://datathief.org/).

For plant diversity, researchers have used the values given by various diversity indices to quantify species diversity. Indices most frequently employed were species richness, species evenness, the Shannon-Wiener diversity index and the Simpson dominance index. Because different indices represent different aspects of species diversity, we compiled data for the above four diversity indices separately from individual studies.

For SOC, sampling depths ranged from $10 \mathrm{~cm}$ to $100 \mathrm{~cm}$, which meant we were unable to establish a common maximum depth 
for the deeper soil layer data set. According to our database, the majority of studies (92\%) had reported soil C data within the top $30 \mathrm{~cm}$ layer. Considering that SOC stocks are mainly concentrated in the upper $30 \mathrm{~cm}$ layer in China's grasslands (Yang et al., 2010), we unified SOC stocks data to a $30 \mathrm{~cm}$ depth. For example, if the SOC data were reported by $10 \mathrm{~cm}$ intervals to a depth of $100 \mathrm{~cm}$ in both grazed and grazing excluded sites, we summed the SOC stocks of the upper $30 \mathrm{~cm}$ for the meta-analysis. In some studies, soil organic matter concentration (SOM, $\mathrm{g} \mathrm{kg}^{-1}$ ) or soil organic $C$ concentration $\left(C_{c}, \mathrm{~g} \mathrm{~kg}^{-1}\right)$ were reported without soil bulk density information. In these cases, we used the following equations to calculate SOC stocks of grasslands $\left(C_{S}\right.$ tha $\left.{ }^{-1}\right)$ (Xie et al., 2007):

$C_{C}=0.58 \times S O M$

When the soil sampling depth is $0-10 \mathrm{~cm}$,

$B D=-0.231 \operatorname{Ln}\left(C_{C}\right)+1.352$

When the soil sampling depth is $>10 \mathrm{~cm}$,

$B D=-0.0422 C_{c}+1.3958$

$C_{s}=B D \times C_{C} \times D \times 10$

where SOM and $C_{c}$ are concentrations of soil organic matter and SOC, respectively, as a percentage of the soil dry mass. $B D$ is the soil bulk density $\left(\mathrm{g} \mathrm{cm}^{-3}\right)$, and $D$ is the soil sampling depth $(\mathrm{cm})$. Eq. (1) assumes that SOM is 58\% SOC (Mann, 1986).

The factor 0.45 was used to convert plant dry biomass to plant $\mathrm{C}$ stocks (Olson et al., 1983). For studies reported plant air dry weight, the water content of air dry grass was considered to be $15 \%$ (Piao et al., 2004).

\subsection{Data analysis}

To quantify the difference of chosen variables between grazed and grazing excluded sites, we used the natural log-transformed response ratio $(\ln R R)$ for estimating the effect size (Hedges et al., 1999; Nave et al., 2011; Wu et al., 2011):

$\ln R R=\ln \left(X_{E} / X_{C}\right)=\ln X_{E}-\ln X_{C}$

The variance of each log response ratio was calculated as:

$V_{\ln R R}=\frac{S_{E}{ }^{2}}{N_{E}\left(X_{E}\right)^{2}}+\frac{S_{C}{ }^{2}}{N_{C}\left(X_{C}\right)^{2}}$

where $X_{E}$ and $X_{C}$ are the mean values of treatment (grazing exclusion) and control (grazing) observations, respectively, $N_{E}$ and $N_{C}$ are the number of replicates of the treatment and the control, respectively, and $S_{E}$ and $S_{C}$ are the standard deviations of the treatment and the control, respectively.

Because it is non-dimensional, the $\ln R R$ is a standardized metric that allows comparison of data between experimental and control observations in different units (Hedges et al., 1999). To facilitate comparison with similar studies, the values of $\ln R R$ were transformed to estimate the percentage change in C stocks and other variables relative to the control (\%), using the equation $\left(e^{\ln R R}-1\right) \times 100 \%$ (Luo et al., 2006).We used a random effect metaanalysis model to calculate the mean effect size for each study, with $95 \%$ confidence intervals (CIs) generated by a bootstrapping procedure based on 4999 iterations permutations (Adams et al., 1997; Rosenberg et al., 2000). This model assumes that all observed variation is not only due to sampling error but to a true random variation, which is preferable in ecological data synthesis, as in our case (Rosenberg et al., 2000; Gurevitch and Hedges, 2001). Using this method, means were considered to be significantly different from one another if their 95\% CIs were non-overlapping, and significantly different from zero if the $95 \%$ CIs did not overlap zero (Gurevitch and Hedges, 2001).
In this database, some studies measured variables in different seasons of a year, and some studies compared several controls (grazed plots with different stocking rate) against a shared treatment plot. In these cases, in order to minimize the nonindependence of the data set, we first calculated effect sizes for each comparison and then pooled these effect sizes by doing a separate meta-analysis (van Kleunen et al., 2010). The estimated pooled mean effect sizes were used in the final analyses. Because we are interested in the temporal patterns of grazing exclusion on ecosystem $\mathrm{C}$ pools, for studies conducted by chronosequence design for grazing exclusion compared with natural grazed grasslands in the same sites, we included each of the data in the analysis. In the final analysis of the SOC data set, we deleted 6 outliers from one paper with extreme high value ( $>100 \%$ increase of SOC stocks (Jing et al., 2014)). However, before doing this elimination, we confirmed that the results were qualitatively the same when including these outliers in the analyses (Song et al., 2012).

To assess whether changes of ecosystem $C$ stocks and plant diversity following grazing exclusion were associated with several continuously varying factors (e.g. duration of grazing exclusion treatment and climatic variables), we tested whether the coefficients for slope in terms of linear models as predictors of variation were significantly different from zero using continuous metaanalyses (Rosenberg et al., 2000). To assess the effects of grassland types on change of plant diversity and ecosystem C stocks, we also categorized those predictor variables (Guo and Gifford, 2002; Song et al., 2014). MAT were divided into $<0^{\circ} \mathrm{C}, 0-2{ }^{\circ} \mathrm{C}, 2-4{ }^{\circ} \mathrm{C}, 4-6^{\circ} \mathrm{C}$, $6-8^{\circ} \mathrm{C},>8{ }^{\circ} \mathrm{C}$, and MAP into $<300 \mathrm{~mm}, 300-500 \mathrm{~mm},>500 \mathrm{~mm}$, the durations of grazing exclusion were classified as $<5$ years and $>5$ years, and grassland types were grouped as temperate steppe, temperate meadow-steppe, temperate desert-steppe, alpine steppe and alpine meadow. Because the effect sizes of soil $\mathrm{C}$ stocks were positively correlated with MAP, we did not further test the heterogeneity among MAP groups for SOC stocks. A mixed effect model was used to compare mean effect sizes between different categories (Rosenberg et al., 2000). The total heterogeneity of a group of comparison $\left(Q_{T}\right)$ is partitioned into within-group $\left(Q_{W}\right)$ and between-group $\left(Q_{b}\right)$ heterogeneity. The $Q_{b}$ statistic can be tested against a Chi-squared distribution with $\mathrm{k}-1$ degrees of freedom. A significant $Q_{b}$ suggests that there are differences among cumulative effect sizes for the groups (Rosenberg et al., 2000; Gurevitch and Hedges, 2001). To test publication bias (i.e. the tendency for journals to publish only those studies with statistically significant results), we checked weighted histograms, funnel plots and normal-quantile plots, performed Spearman's rank-order correlation tests, and estimated failsafe numbers for all chosen variables (Palmer, 1999;). The graphical and statistical tests indicate the absence of publication bias (Table A.1, Figs. A.1 -A.27). All metaanalytical calculations were conducted with the software MetaWin v. 2.1 (Rosenberg et al., 2000; Gurevitch and Hedges, 2001)

Because we are interested in soil $C$ sequestration dynamics after $\mathrm{GE}$, we further estimated the percentage change in the annual rate of SOC sequestration $\left(S O C_{R} \% \mathrm{yr}^{-1}\right)$ using the following equation:

$S O C_{R}=\left(S O C_{E}-S O C_{C}\right) / S O C_{C} / T \times 100$

where $S O C_{E}$ and $S O C_{C}$ are the mean SOC stock values of treatment (grazing exclusion) and control (grazing) observations, and $T$ is the duration of GE practice (yr).

Then we used a nonlinear regression to analyze the relationship between the soil $C$ sequestration rate and the duration of grazing exclusion, as this algorithm is usually the most representative of the nonlinear nature of SOC dynamics over time (West and Post, 2002). As different types of grasslands may have different SOC dynamics after grazing exclusion, we performed the nonlinear regression in temperate steppe and alpine meadow, separately, according to data 
Table 1

Ecosystem carbon stocks $\left(\mathrm{MgCha}^{-1}\right)$ in grazed and grazing excluded sites ( mean $\pm \mathrm{SE}$ ). $\mathrm{C}=$ carbon; $\mathrm{AGB}=$ aboveground biomass; $\mathrm{BGB}=$ belowground biomass; $\mathrm{SOC}=$ soil organic carbon.

\begin{tabular}{lll}
\hline & Grazed sites & Grazing excluded site \\
\hline C stored in AGB & $0.53 \pm 0.05$ & $0.98 \pm 0.12$ \\
C stored in aboveground litter & $0.18 \pm 0.06$ & $0.34 \pm 0.09$ \\
C stored in BGB & $4.19 \pm 0.44$ & $5.48 \pm 0.62$ \\
SOC stock & $47.1 \pm 4.4$ & $55.1 \pm 5.4$ \\
Total & 52.0 & 62.0 \\
\hline
\end{tabular}

availability. The SPSS 16.0 was used for the nonlinear regression analyses.

\section{Results}

We found 78 publications with 447 data points suitable for the meta-analysis according to our selection criteria. The database covers RGLG program implemented areas in 9 provinces (or autonomous regions) of China (Fig. B.1). The mean duration of grazing exclusion treatment was 8 years with a range from 1 to 30 years (Table B.1).

\subsection{Overall effects of grazing exclusion on carbon stocks and plant diversity}

Across all studies included in our meta-analysis, grazing exclusion increased total ecosystem carbon stocks by $19.1 \%$, from an average $52.0 \mathrm{MgCha}^{-1}$ in grazed to $62.0 \mathrm{MgCha}^{-1}$ in fenced sites (Table 1). Soil accounted for approximately $90 \%$ of the total ecosystem carbon pool (Table 1). Carbon stored in AGB, aboveground litter mass, BGB, and soil were $84.7 \%, 111.6 \%, 25.5 \%$ and $14.4 \%$ higher in grazing excluded than grazed sites, respectively (Fig. 1a). In average,plant coverage, soil available nitrogen, available phosphorous, and soil microbial biomass carbon also significantly increased by $52.0 \%, 21.7 \%, 22.8 \%$, and $26.3 \%$, respectively, under grazing exclusion across all studies (Fig. 1a). In terms of species diversity, generally, grazing exclusion did not have any noticeable effects on all diversity indices, including species richness, species evenness, the Shannon index and the Simpson index (Fig. 1b).

\subsection{Factors influencing the effects of grazing exclusion on plant diversity and ecosystem carbon stock}

The duration of grazing exclusion was an important determinant of changes of species richness $\left(Q_{b}=6.78, P<0.05\right)$ and species evenness $\left(Q_{b}=6.18, P<0.05\right)$ (Table 2$)$. Species richness increased in the first five years, but no change after five years of grazing exclusion (Fig. 2a). Species evenness showed a significant decrease when grazing exclusion lasted more than 10 years (Fig. 2b). After grazing exclusion, species richness increased significantly in temperate steppe and alpine steppe, but did not change in alpine meadow (Fig. 2). Grazing exclusion had no obvious effect on species evenness in different types of grasslands (Fig. 2).

Precipitation and grassland type affected the magnitude of increment of AGB after grazing exclusion (Table 2, Fig. 3a). Increases in AGB were significantly greater in areas with MAP ranging from 300 to $500 \mathrm{~mm}(103.1 \%)$ and $>500 \mathrm{~mm}(88.3 \%)$ than in areas with MAP $<300 \mathrm{~mm}(33.2 \%)\left(Q_{b}=10.40, P<0.01\right)$ (Table 2, Fig. 3a). Grazing exclusion in temperate steppe, temperate meadow-steppe and alpine meadow sequestrated significantly more carbon in AGB than in temperate desert-steppe $\left(Q_{b}=20.07, P<0.01\right)$ (Table 2, Fig. 3a). There were no significant differences in mean effect sizes of BGB among different categories (Table 2). Grazing exclusion had little effect on BGB in areas with MAP less than $300 \mathrm{~mm}$, but significantly increased BGB in areas with MAP above $300 \mathrm{~mm}$ (Fig. 3b).

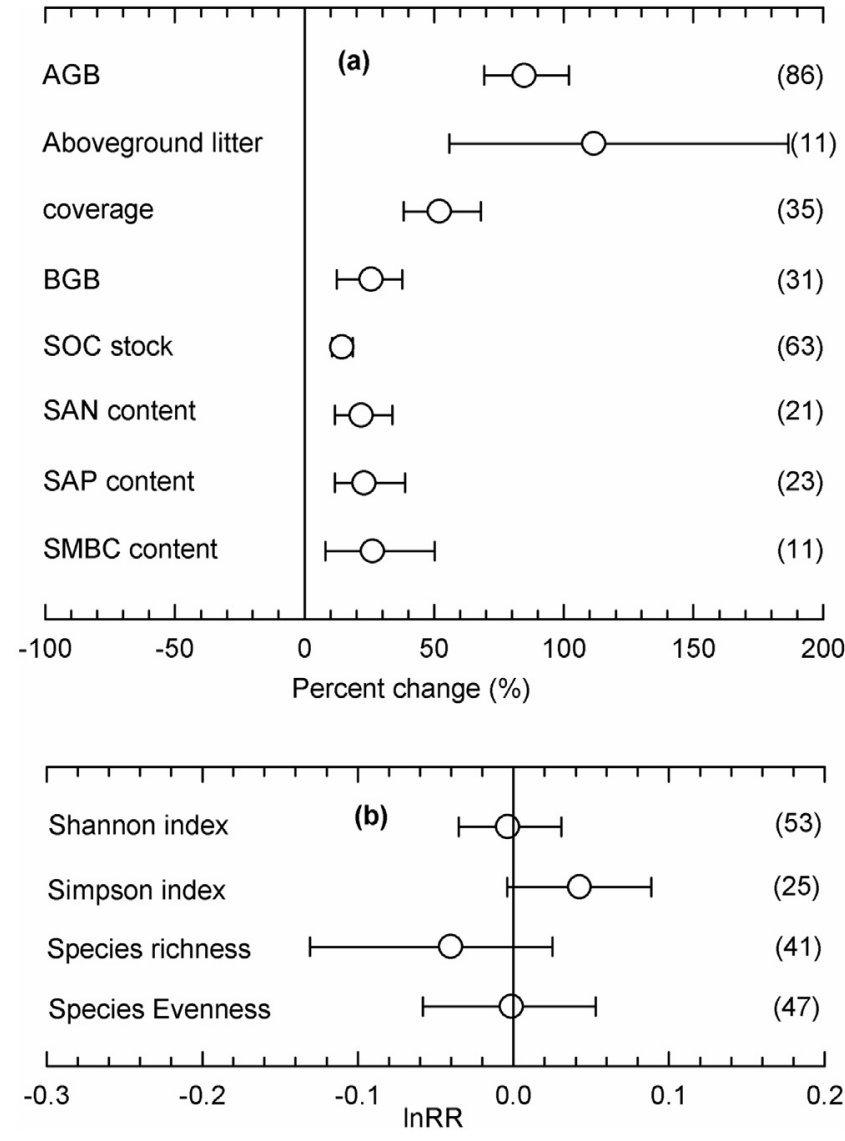

Fig. 1. Percentage change of variables related to ecosystem $C$ stock (a), and mean effect size of plant diversity (b) under grazing exclusion compared with grazing sites. Error bars are 95\% bootstrapped confidence intervals. Number of observations is given to right of the graph in parentheses. $R R=$ response ratio; $\mathrm{AGB}=$ aboveground biomass; $\mathrm{BGB}=$ belowground biomass; $\mathrm{SOC}=$ soil organic carbon; $\mathrm{SAN}=$ soil available nitrogen; $\mathrm{SAP}=$ soil available phosphorus; $\mathrm{SMBC}=$ soil microbial biomass carbon.

BGB increased obviously in temperate meadow steppe and temperate steppe in response to grazing exclusion (Fig. 3b). Grassland type and climatic factors had significant impact on changes in soil carbon stocks following grazing exclusion (Table 2, B.2). Grazing exclusion had significant soil carbon sequestration potential in all types of grasslands except temperate desert-steppe (Fig. 3c). Responses of SOC stocks to grazing exclusion were significantly increased with MAP $(P<0.01)$ but decreased with MAT $(P<0.01)$ (Table B.2, Fig. 4). Soil carbon sequestration rates presented hyperbolic decay curves with the duration of grazing exclusion, in both alpine meadow $\left(R^{2}=0.32, P<0.01\right)$ (Fig. 5a) and temperate steppe $\left(\mathrm{R}^{2}=0.21, P<0.05\right)$ (Fig. 5b).

\section{Discussion}

\subsection{Increase of ecosystem carbon stocks by grazing exclusion}

Our comprehensive meta-analysis demonstrated a consistent positive overall effect of grazing exclusion on grassland biomass and soil carbon stocks. It is well observed that long-term excessive grazing constrains plant growth, disrupts soil structure, and thus renders ecosystem degradation in China's grasslands. Degradation disturbs soil nutrient cycling and induces a mass of carbon loss (Wiesmeier et al., 2009; Tanentzap and Coomes, 2012). Our analysis prove that grazing exclusion can reverse grassland degradation and possess carbon sequestration potential. Our results are in accord with on-site and regional studies, which indicate increased ecosys- 
Table 2

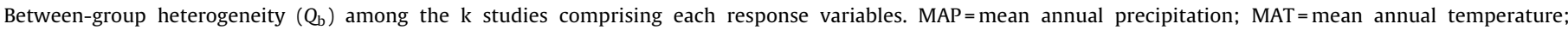
$\mathrm{GT}=$ grassland type $\mathrm{AGB}=$ aboveground biomass; $\mathrm{BGB}=$ belowground biomass; $\mathrm{SOC}=$ soil organic carbon

\begin{tabular}{|c|c|c|c|c|c|c|}
\hline \multicolumn{2}{|c|}{ Response variables } & \multirow{2}{*}{$\frac{\mathrm{k}}{53}$} & \multirow{2}{*}{$\begin{array}{l}\text { MAP } \\
\text { NA }\end{array}$} & \multirow{2}{*}{$\begin{array}{l}\text { MAT } \\
\text { NA }\end{array}$} & \multirow{2}{*}{$\begin{array}{l}\text { GT } \\
4.35\end{array}$} & \multirow{2}{*}{$\frac{\text { Duration }}{2.76}$} \\
\hline Plant diversity & Shannon index & & & & & \\
\hline & Simpson index & 25 & NA & NA & 0.41 & 3.83 \\
\hline & Species richness & 41 & NA & NA & $8.45^{*}$ & $6.78^{*}$ \\
\hline & Species evenness & 47 & NA & NA & 1.22 & $6.18^{*}$ \\
\hline \multirow{3}{*}{$\begin{array}{l}\text { Ecosystem carbon } \\
\text { stock }\end{array}$} & AGB & 86 & $10.40^{* *}$ & 5.22 & $20.07^{* *}$ & NA \\
\hline & BGB & 31 & 3.87 & 1.67 & 0.19 & NA \\
\hline & SOC & 63 & NA & NA & $16.49^{*}$ & NA \\
\hline
\end{tabular}

Note: ${ }^{* *}$ indicate $P<0.01 ;{ }^{*}$ indicate $P<0.05$.

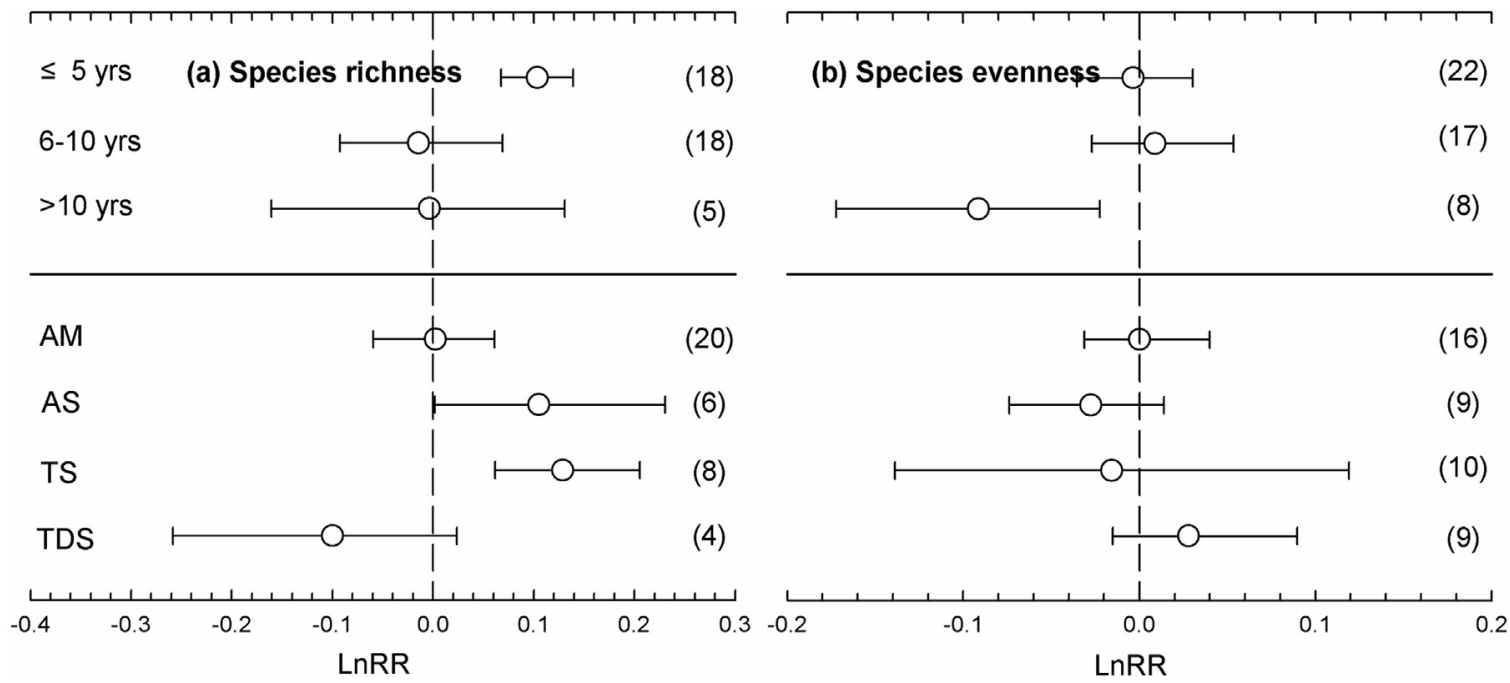

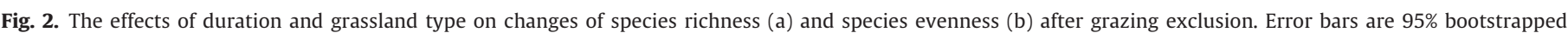

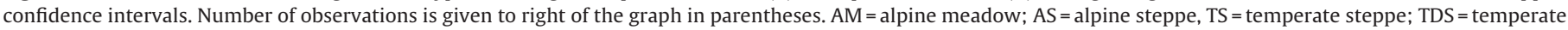
desert-steppe.

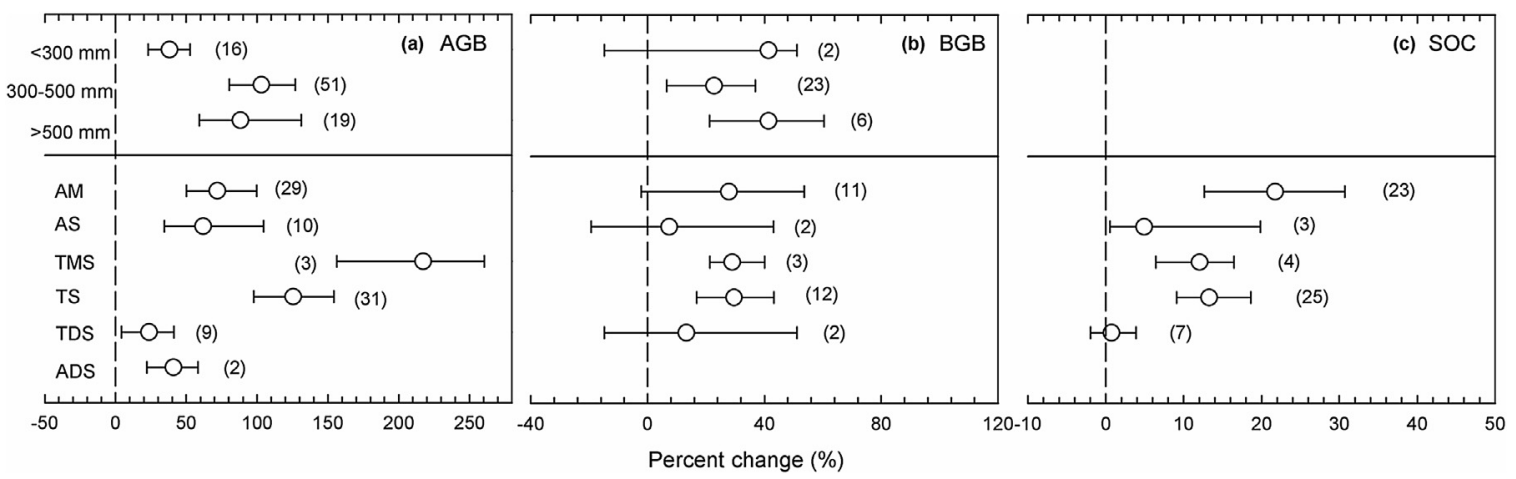

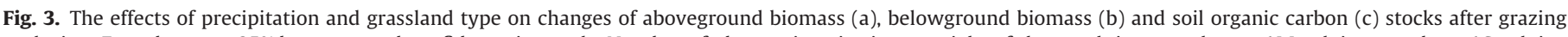

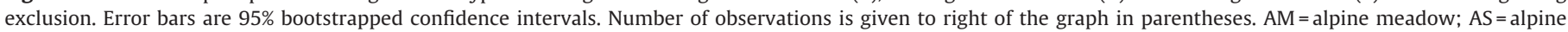
steppe; TMS = temperate meadow-steppe; TS = temperate steppe; TDS = temperate desert-steppe.

tem carbon stocks induced by grazing exclusion can meet the need to restore land degradation (McIntosh and Allen, 1998; Conant and Paustian, 2002; Mekuria et al., 2007; Mekuria and Veldkamp, 2012; Zhou et al., 2007), but are inconsistent with studies carried out in grasslands with little disturbance, for example, in the U.S. (Schuman et al., 1999; Reeder and Schuman, 2002; Derner et al., 2006). By comparing our case with the above studies, we deemed that the positive effects of grazing exclusion were dependent on widespread degradation of grasslands and lower baseline of observed indicators. In China, most of grasslands are overgrazed and degraded (Akiyama and Kawamura, 2007; Han et al., 2008). The grazing intensity exceeds double carrying capacity of grass- land (Chen et al., 2003). Overgrazing rates are usually over $150 \%$ and even higher than $300 \%$ in some place (Han et al., 2008). Approximately more than $30 \%$ of grasslands in north China are considered to be moderately to severely degraded (Han et al., 2008; Li et al., 2013). For the U.S. Great Plains, the experiments were conducted in areas without grazing by domestic livestock for decades (Reeder and Schuman, 2002; Derner et al., 2006).

The majority of carbon is stored in soils in China's grasslands (Ni, 2002). SOC is determined by the balance between carbon input from plant productivity, litter decomposition, root turnover and animal excreta, and carbon output through soil respiration, soil erosion and leaching (Cui et al., 2005). In our case, several mech- 

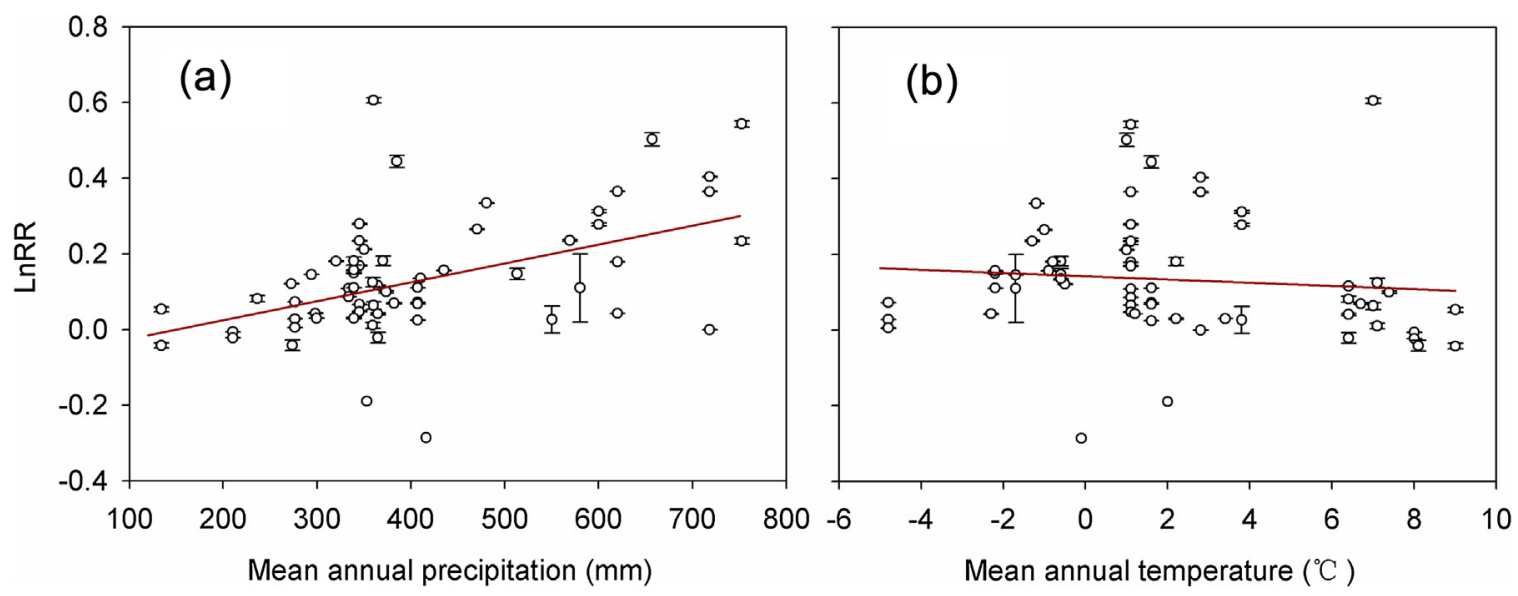

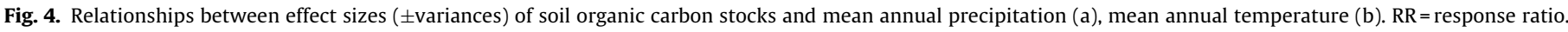
See Table 2 for statistical results.

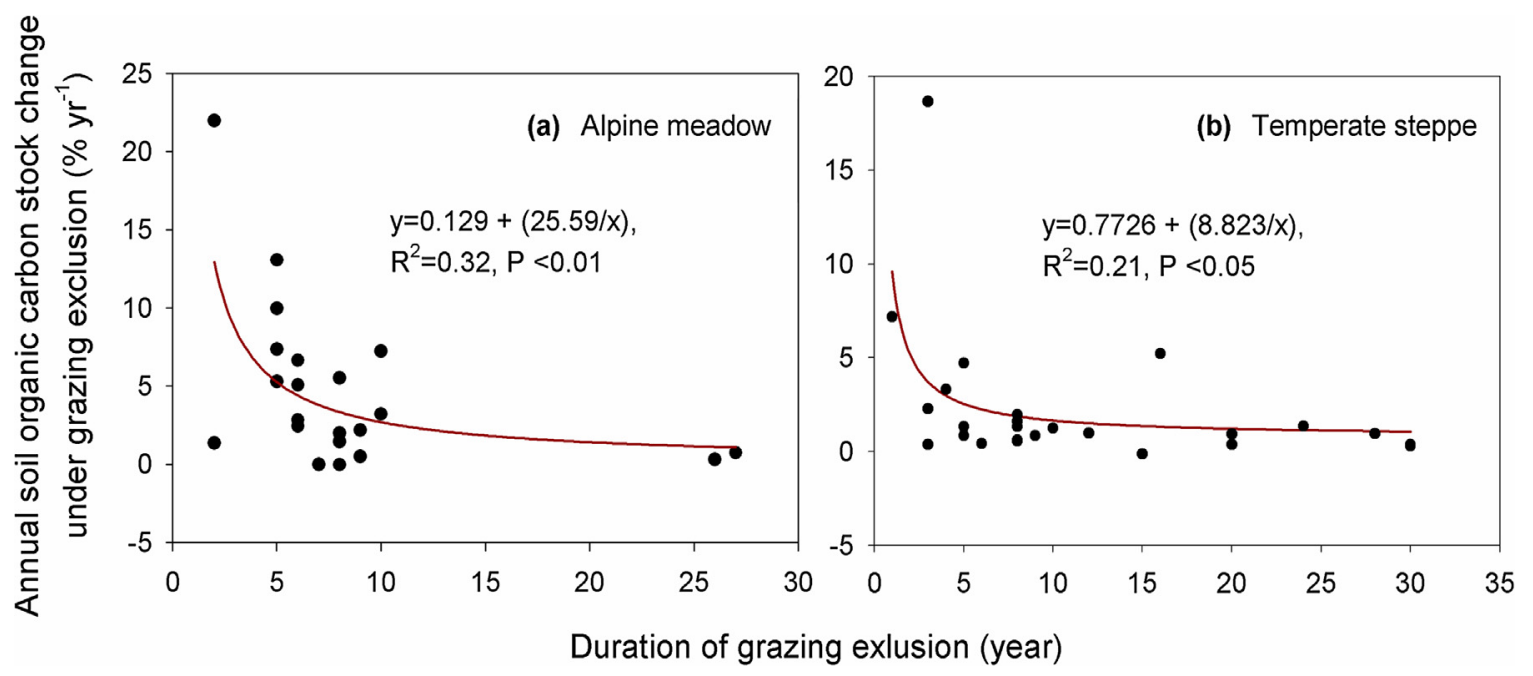

Fig. 5. The percentage change in annual soil organic carbon sequestration rates in alpine meadow and temperate steppe under grazing exclusion practice.

anisms may explain the increment of SOC stock in response to grazing exclusion. First, organic matter input from AGB, litter mass and root mass all increased remarkably after grazing exclusion (Su et al., 2005; Pei et al., 2006; Shi et al., 2010; X. Wu et al., 2014). Second, the wide use of animal excrement for fuel energy by local herders decreased the carbon return from livestock animal manure was used for fuel energy by local herders (He et al., 2009; Xu et al., 2013). In addition, the significant increases in plant coverage leads to less soil surface being directly exposed to wind erosion in fenced sites, which could prevent the SOC loss caused by soil erosion in grasslands (Mekuria et al., 2007). Moreover, excluding livestock stamping enhanced soil aggregate structure in fenced sites, then weakened SOM decomposition and protect the soil from water and wind erosion (Belnap, 2003; Neff et al., 2005).

\subsection{Effects of grazing exclusion on plant diversity}

In our meta-analysis, mean effect sizes demonstrated that grazing exclusion had little effect on recovering plant diversity in China's grasslands. The results are in line with some studies in western U.S. (Loeser et al., 2007) and in central Spain (Peco et al., 2005, 2006). With regards to the duration of grazing exclusion, we found that short-term (no more than 5 years) grazing exclusion remarkably increased species richness, but the effects were not significant in the long run. For species evenness, the threshold from neutral to negative effects of grazing exclusion occurs after approximately ten years. Several explanations have been suggested for these patterns. Excessive grazing and trampling by domestic animals may inhibit plant reproduction and regeneration, and resulting in the loss of some associated species in overgrazed grasslands (Sternberg et al., 2000; Firincioglu et al., 2007). Therefore, removing grazing pressure would facilitate the growth of suppressed species and increase species richness at the early stage of grazing exclusion (Luno et al., 1997; Shang et al., 2008). However, along with vegetation succession proceeding, the long-term absence of disturbance led to the preponderance of dominant species over time. Additionally, litter accumulation also hindered plant recruitment in grazing excluded grasslands, which would decrease species evenness and lead to loss of species (Oba et al., 2001; Zhu et al., 2012). For example, it was inclined to favor dominant forages such as Kobresia tibetica and Poa pratensis, but restrained the growth of other herbs after long-term grazing exclusion in an alpine meadow (Wu et al., 2009).

\subsection{Factors influencing the effects of grazing exclusion on carbon sequestration}

Overall, climate appeared to strongly modify the effects of grazing exclusion on ecosystem carbon stocks in China's grasslands. As water was the major factor that limited plant growth in natural grasslands (St Clair et al., 2009), the increases in aboveground 
production were significantly greater in areas with the preferred amount of precipitation ( $>300 \mathrm{~mm}$ ). Piñeiro et al. (2009) concluded that the effects of grazing exclusion on root biomass were positive at mesic locations (400-850 mm of MAP) (Fuhlendorf et al., 2002; Kauffman et al., 2004; Xie and Wittig, 2004; Derner et al., 2006; Gao et al., 2011), but negative at humid and dry conditions (McNaughton et al., 1998; Frank et al., 2002; Pucheta et al., 2004; Reeder et al., 2004; Cui et al., 2005). Similarly, in our study, MAP ranged from $134 \mathrm{~mm}$ to $752 \mathrm{~mm}$ across all experimental sites. Grazing exclusion had no obvious effects on BGB in dry areas $(\mathrm{MAP}<300 \mathrm{~mm}$ ) but significantly increased BGB in areas with MAP over $300 \mathrm{~mm}$. Our results indicated that the effects of grazing exclusion on SOC stocks were increased with MAP but decreased with MAT, in coincidence with other syntheses (Conant and Paustian, 2002; Derner and Schuman, 2007). Derner and Schuman (2007) synthesized results from grazing experiments in the North American Great Plains and found a negative relationship of soil carbon sequestration with MAP in the $0-30 \mathrm{~cm}$ soil layer. Because they considered livestock grazing as the experimental treatment, the trend of precipitation effects was in line with our results. Likewise, Conant and Paustian (2002) also demonstrated a positive linear relationship between potential carbon sequestration and MAP in a global perspective. It is suggested that greater precipitation could amplify the magnitude of the grazing exclusion effects on grassland carbon stocks in China. The decreasing trend of soil carbon sequestration with MAT may resulted from accelerated decomposition rate of organic matter along the temperature gradient (Burke et al., 1995; Jobbágy and Jackson, 2000). The response of soil carbon stocks also differed in relation to grassland type, as we detected only small effects of grazing exclusion on soil carbon stocks in water limited temperate desert-steppe, but notable increases in other grassland types such as temperate steppe, temperate meadow-steppe and alpine meadow. This response pattern was similar to what found in BGB, which indicated that root mass may be one primary source of soil carbon input contributing to SOC change (Gill et al., 1999; Gao et al., 2011).

Soil carbon recovery with improved grassland management in degraded land typically lagged behind plant production recovery and would take a long time (Burke et al., 1995; Werth et al., 2005; Raiesi and Asadi, 2006). In this study, we found that the annual soil carbon sequestration rates showed a hyperbolic decay over time in both alpine meadow and temperate steppe. Our findings indicate that soil carbon sequestration is more efficient in the early phrase in fenced grasslands, while SOC may reach a new equilibrium at some certain time following adoption of grazing exclusion practice. But it is difficult to obtain the exact time when the soil carbon reaches saturation following grazing exclusion, because the dynamics of soil carbon accumulation commonly varied in specific sites. For example, in a Leymus chinensis grassland in Inner Mongolia, researchers found that the threshold from carbon sink to carbon source occurred at approximately 20 years duration after elimination of livestock grazing (Bai et al., 2004; He et al., 2008). In the Stipa bungeana grasslands of Yunwu Mountain reserve in Ningxia province, long-term field observation data indicated that soil carbon sequestration had lasted for about 30 years in grazing excluded sites (Deng et al., 2014).

\subsection{Implications for sustainable grassland management strategies}

Our synthesis indicates that grazing exclusion is effective not only to restore vegetation but to potentially sequestered carbon in overgrazed grasslands in China. This practice is also proved to increase terrestrial carbon stocks at regional scales (Tanentzap and Coomes, 2012). Therefore, it is expected a great potential to improve forage production and carbon sequestration for the national program of RGLG in China because of large area, long-term implementation and low baseline at the beginning. The effectiveness of this program is mainly controlled by precipitation and subsequent grassland type. Therefore, the program implemented in humid areas is expected its positive effects on vegetation restoration and carbon sequestration. But in arid areas, grazing exclusion is not efficient enough to restore degraded vegetation. The measure of reducing amount of livestock in combination with planting sown pasture in water available area might be a better choice.

Overall, our results show that grazing exclusion had little effects on species diversity. Species richness increased with short-term grazing exclusion (less than five years), but species evenness presented decline after 10 years. The findings reveal a possible trade-off between carbon sequestration and diversity maintenance in China's grasslands. Therefore, we proposed that short-term grazing exclusion is essential and important for restoring degraded grasslands (Su et al., 2005; Shang et al., 2008; Liu et al., 2014). Longterm grazing exclusion may not be a good management option according to our results, for the following reasons. First, long-term grazing exclusion obviously decreases species richness and evenness and hinder seedling recruitment into the plant community (Wu et al., 2009; Cheng et al., 2011; Zhu et al., 2012). Second, carbon fixation is less efficient in long-term fenced grasslands, as the soil carbon sequestration rate go down sharply after ten years. In addition, fencing also has negative effects on the migration and reproduction of wild animals. Too much litter accumulation in the fenced sites might induce increasing risk of wild fire (Bird et al., 2000; Ward et al., 2007). Therefore, grazing exclusion practice should not be too long for sake of economic costs and rangeland use (Papanastasis, 2009). Considering the comprehensive effectiveness of vegetation recovery, plant diversity maintenance and carbon sequestration, we recommended that grazing exclusion practice could cease after approximately six to ten years.

The RGLG program has been implemented more than ten years since 2003. We suggest the fences should be open now. Other appropriately alternative measures have to be taken into consideration. For example, periodic grazing (restricted grazing in certain seasons) and/or rotational grazing (restricted grazing in certain areas) could be considered as beneficial measures for sustainable rangeland use (Wu et al., 2009; Papanastasis, 2009). Besides, integrative management such as fertilization, sand-fixing measures, reseeding andr sown pastures should be considered during grassland restoration practice in order to increase efficiency and minimize negative effects (Shirato et al., 2005; Zhao et al., 2007; Wu et al., 2009; Li et al., 2013).

\section{Conclusion}

In this meta-analysis, we found that grazing exclusion had positive effects on plant cover, ecosystem carbon stocks and soil nutrient content, but had limited effect on diversity recovery in China's grasslands. Our results demonstrated that grazing exclusion is an effective measure to restore degraded grasslands. It is expected that there is great potential for carbon sequestration from the RGLG project, especially in humid areas. In arid area, reducing livestock population and planting sown pasture might be alternative options as grazing exclusion is inefficient in this area. Taking account of the trade-off relationship between carbon sequestration and plant diversity maintenance, the RGLG program over ten years should be ceased. Other traditional practice including periodic and rotation grazing should be integrated into management strategies.

\section{Acknowledgements}

This work was supported by the "Strategic Priority Research Program" of the Chinese Academy of Sciences, Climate Change: Carbon 
Budget and Relevant Issues (Grant No. XDA05060700). We thank Dr. Yaobing Song for his technical help while we prepare this paper. Thanks are also due to $\mathrm{Dr}$ Jianshuang Wu for his helpful comments.

\section{Appendix A. Supplementary data}

Supplementary data associated with this article can be found, in the online version, at http://dx.doi.org/10.1016/j.ecoleng.2016.06. 124.

\section{References}

Adams, D.C., Gurevitch, J., Rosenberg, M.S., 1997. Resampling tests for meta-analysis of ecological data. Ecology 78, 1277-1283.

Akiyama, T., Kawamura, K., 2007. Grassland degradation in China: methods of monitoring, management and restoration. Grassland Sci. 53, 1-17.

Altesor, A., Oesterheld, M., Leoni, E., Lezama, F., Rodriguez, C., 2005. Effect of grazing on community structure and productivity of a Uruguayan grassland. Plant Ecol. 179, 83-91.

Anderson, J., 1991. The effects of climate change on decomposition processes in grassland and coniferous forests. Ecol. Appl., 326-347.

Bai, Y.F., Han, X.G., Wu, J.G., Chen, Z.Z., Li, L.H., 2004. Ecosystem stability and compensatory effects in the Inner Mongolia grassland. Nature 431, 181-184.

Belnap, J., 2003. The world at your feet: desert biological soil crusts. Front. Ecol. Environ. 1, 181-189.

Biondini, M.E., Patton, B.D., Nyren, P.E., 1998. Grazing intensity and ecosystem processes in a northern mixed-grass prairie, USA. Ecol. Appl. 8, 469-479.

Bird, M., Veenendaal, E., Moyo, C., Lloyd, J., Frost, P., 2000. Effect of fire and soil texture on soil carbon in a sub-humid savanna (Matopos, Zimbabwe). Geoderma 94, 71-90.

Burke, I.C., Lauenroth, W.K., Coffin, D.P., 1995. Soil organic-matter recovery in semiarid grasslands - implications for the conservation reserve program. Ecol. Appl. 5, 793-801.

Chen, Z.Z., Wang, S.P., Wang, Y.F., 2003. Update progress on grassland ecosystem research in Inner Mongolia steppe. Chin. Bull. Bot. 20, 423-429.

Cheng, J., Wu, G.L., Zhao, L.P., Li, Y., Li, W., Cheng, J.M., 2011. Cumulative effects of 20 -year exclusion of livestock grazing on above- and belowground biomass of typical steppe communities in arid areas of the Loess Plateau, China. Plant Soi Environ. 57, 40-44.

Conant, R.T., Paustian, K., 2002. Potential soil carbon sequestration in overgrazed grassland ecosystems. Global Biogeochem. Cycles 16, 90

Cui, X.Y., Wang, Y.F., Niu, H.S., Wu, J., Wang, S.P., Schnug, E., Rogasik, J., Fleckenstein, J., Tang, Y.H., 2005. Effect of long-term grazing on soil organic carbon content in semiarid steppes in Inner Mongolia. Ecol. Res. 20, 519-527.

Deng, L., Zhang, Z., Shangguan, Z., 2014. Long-term fencing effects on plant diversity and soil properties in China. Soil Tillage Res. 137, 7-15.

Derner, J.D., Schuman, G.E., 2007. Carbon sequestration and rangelands: a synthesis of land management and precipitation effects. J. Soil Water Conserv. 62, 77-85.

Derner, J.D., Boutton, T.W., Briske, D.D., 2006. Grazing and ecosystem carbon storage in the North American Great Plains. Plant Soil 280, 77-90.

Dullinger, S., Dirnbock, T., Greimler, J., Grabherr, G., 2003. A resampling approach for evaluating effects of pasture abandonment on subalpine plant species diversity. J. Veg. Sci. 14, 243-252.

Eweg, H.P.A., Van Lammeren, R., Deurloo, H., Woldu, Z., 1998. Analysing degradation and rehabilitation for sustainable land management in the highlands of Ethiopia. Land Degrad. Dev. 9, 529-542.

Firincioglu, H.K., Seefeldt, S.S., Sahin, B., 2007. The effects of long-term grazing exclosures on range plants in the Central Anatolian Region of Turkey. Environ. Manag. 39, 326-337.

Frank, D.A., Kuns, M.M., Guido, D.R., 2002. Consumer control of grassland plant production. Ecology 83, 602-606.

Fuhlendorf, S.D., Zhang, H., Tunnell, T.R., Engle, D.M., Cross, A.F., 2002. Effects of grazing on restoration of southern mixed prairie soils. Restor. Ecol. 10, 401-407.

Gao, Y.H., Zeng, X.Y., Schumann, M., Chen, H.A., 2011. Effectiveness of exclosures on restoration of degraded alpine meadow in the eastern Tibetan Plateau. Arid Land Res. Manag. 25, 164-175.

Gill, R., Burke, I.C., Milchunas, D.G., Lauenroth, W.K., 1999. Relationship between root biomass and soil organic matter pools in the shortgrass steppe of eastern Colorado. Ecosystems 2, 226-236.

Golodets, C., Kigel, J., Sternberg, M., 2010. Recovery of plant species composition and ecosystem function after cessation of grazing in a Mediterranean grassland. Plant Soil 329, 365-378.

Guo, L.B., Gifford, R.M., 2002. Soil carbon stocks and land use change: a meta analysis. Global Change Biol. 8, 345-360.

Gurevitch, J., Hedges, L.V., 1999. Statistical issues in ecological meta-analyses. Ecology 80, 1142-1149.

Gurevitch, J., Hedges, L., 2001. Meta-analysis: combining the results of independent experiments. In: Sheiner, S.M., Gurevitch, J. (Eds.), Design and Analysis of Ecological Experiments. , 2nd ed. Oxford University Press, UK.

Hafner, S., Unteregelsbacher, S., Seeber, E., Lena, B., Xu, X.L., Li, X.G., Guggenberger, G., Miehe, G., Kuzyakov, Y., 2012. Effect of grazing on carbon stocks and assimilate partitioning in a Tibetan montane pasture revealed by $13 \mathrm{CO}_{2}$ pulse labeling. Global Change Biol. 18, 528-538.

Han, J.G., Zhang, Y.J., Wang, C.J., Bai, W.M., Wang, Y.R., Han, G.D., Li, L.H., 2008. Rangeland degradation and restoration management in China. Rangeland J. 30 233-239.

He, N.P., Yu, Q., Wu, L., Wang, Y.S., Han, X.G., 2008. Carbon and nitrogen store and storage potential as affected by land-use in a Leymus chinensis grassland of northern China. Soil Biol. Biochem. 40, 2952-2959.

He, Y.X., Sun, G., Wu, N., Luo, P., 2009. Effects of dung deposition on grassland ecosystem:A review. Chin. J. Ecol. 28, 322-328.

Hedges, L.V., Olkin, I., Statistiker, M., 1985. Statistical Methods for Meta-Analysis Academic Press, Orlando, FL.

Hedges, L.V., Gurevitch, J., Curtis, P.S., 1999. The meta-analysis of response ratios in experimental ecology. Ecology 80, 1150-1156.

Jeddi, K., Chaieb, M., 2010. Changes in soil properties and vegetation following livestock grazing exclusion in degraded arid environments of South Tunisia. Flora 205, 184-189.

Jing, Z.B., Cheng, J.M., Su, J.S., Bai, Y., Jin, J.W., 2014. Changes in plant community composition and soil properties under 3-decade grazing exclusion in semiarid grassland. Ecol. Eng. 64, 171-178.

Jobbágy, E.G., Jackson, R.B., 2000. The vertical distribution of soil organic carbon and its relation to climate and vegetation. Ecol. Appl. 10, 423-436.

Kauffman, J.B., Thorpe, A.S., Brookshire, E.N.J., 2004. Livestock exclusion and belowground ecosystem responses in riparian meadows of Eastern Oregon. Ecol. Appl. 14, 1671-1679.

Lal, R., 2004. Soil carbon sequestration impacts on global climate change and food security. Science 304, 1623-1627.

Leriche, H., LeRoux, X., Gignoux, J., Tuzet, A., Fritz, H., Abbadie, L., Loreau, M., 2001 Which functional processes control the short-term effect of grazing on net primary production in grasslands? Oecologia 129, 114-124.

Li, X.D., Fu, H., Guo, D., Dong, X.Y., Wan, C.G., 2008. Effects of land-use regimes on carbon sequestration in the Loess Plateau, northern China. N. Z. J. Agric. Res. 51 45-52.

Li, X.L., Gao, J., Brierley, G., Qiao, Y.M., Zhang, J., Yang, Y.W., 2013. Rangeland degradation on the Qinghai-Tibet Plateau: implications for rehabilitation. Land Degrad. Dev. 24, 72-80.

Liu, J.G., Diamond, J., 2005. China's environment in a globalizing world. Nature 435 1179-1186.

Liu, M., Liu, G.H., Wu, X., Wang, H., Chen, L., 2014. Vegetation traits and soil properties in response to utilization patterns of grassland in Hulun Buir city, inner Mongolia, China. Chin. Geogr. Sci. 24, 471-478.

Loeser, M.R.R., Sisk, T.D., Crews, T.E., 2007. Impact of grazing intensity during drought in an Arizona grassland. Conserv. Biol. 21, 87-97.

Luno, C.M., Gcia, M.E., Vazquez, H.B., 2007. Changes in the botanical composition of two rangelands in Zacatecas, Mexico, under exclusion and grazing. Agrociencia 31, 313-321.

Luo, Y.Q., Hui, D.F., Zhang, D.Q., 2006. Elevated CO2 stimulates net accumulations of carbon and nitrogen in land ecosystems: a meta-analysis. Ecology 87, 53-63.

MAO. Monitoring report of national grassland, 2006. Ministry of Agriculture the People's Republic of China, http://english.agri.gov.cn/; 2007.

MAO. Monitoring report of national grassland, 2013. Ministry of Agriculture the People's Republic of China, http://english.agri.gov.cn/; 2014.

Mann, L.K., 1986. Changes in soil carbon storage after cultivation. Soil Sci. 142, 279-288.

Mayer, R., Kaufmann, R., Vorhauser, K., Erschbamer, B., 2009. Effects of grazing exclusion on species composition in high-altitude grasslands of the Central Alps. Basic Appl. Ecol. 10, 447-455.

McIntosh, P.D., Allen, R.B., 1998. Effect of exclosure on soils, biomass, plant nutrients, and vegetation, on unfertilised steeplands, Upper Waitaki District, South Island, New Zealand. N. Z. J. Ecol. 22, 209-217.

McNaughton, S.J., Banyikwa, F.F., McNaughton, M.M., 1998. Root biomass and productivity in a grazing ecosystem: the Serengeti. Ecology 79, 587-592.

McSherry, M.E., Ritchie, M.E., 2013. Effects of grazing on grassland soil carbon: a global review. Global Change Biol. 19, 1347-1357.

Meissner, R.A., Facelli, J.M., 1999. Effects of sheep exclusion on the soil seed bank and annual vegetation in chenopod shrublands of South Australia. J. Arid Environ. 42, 117-128.

Mekuria, W., Veldkamp, E., 2012. Restoration of native vegetation following exclosure establishment on communal grazing lands in Tigray, Ethiopia. Appl. Veg. Sci. 15, 71-83.

Mekuria, W., Veldkamp, E., Halle, M., Nyssen, J., Muys, B., Gebrehiwota, K., 2007. Effectiveness of exclosures to restore degraded soils as a result of overgrazing in Tigray, Ethiopia. J. Arid Environ. 69, 270-284.

Milchunas, D.G., Lauenroth, W.K., 1993. Quantatative effects of grazing on vegetation and soils over a global range of environments. Ecol. Monogr. 63, 327-366.

Nave, L.E., Vance, E.D., Swanston, C.W., Curtis, P.S., 2011. Fire effects on temperate forest soil C and N storage. Ecol. Appl. 21, 1189-1201.

Neff, J.C., Reynolds, R.L., Belnap, J., Lamothe, P., 2005. Multi-decadal impacts of grazing on soil physical and biogeochemical properties in southeast Utah. Ecol Appl. 15, 87-95.

Ni, J., 2002. Carbon storage in grasslands of China. J. Arid Environ. 50, 205-218.

Oba, G., Vetaas, O.R., Stenseth, N.C., 2001. Relationships between biomass and plant species richness in arid-zone grazing lands. J. Appl. Ecol. 38, 836-845.

Olff, H., Ritchie, M.E., 1998. Effects of herbivores on grassland plant diversity. Trends Ecol. Evol. 13, 261-265. 
Olson, J.S., Watts, J.A., Allison, L.J., 1983. Carbon in Live Vegetation of Major World Ecosystem. Oak Ridge National Laboratory, Oak Ridge, pp. 50-51.

Palmer, A.R., 1999. Detecting publication bias in meta-analyses: a case study of fluctuating asymmetry and sexual selection. Am. Nat. 154, 220-233.

Papanastasis, V.P., 2009. Restoration of degraded grazing lands through grazing management: can it work? Restor. Ecol. 17, 441-445.

Peco, B., de Pablos, I., Traba, J., Levassor, C., 2005. The effect of grazing abandonment on species composition and functional traits: the case of dehesa grasslands. Basic Appl. Ecol. 6, 175-183.

Peco, B., Sanchez, A.M., Azcarate, F.M., 2006. Abandonment in grazing systems: consequences for vegetation and soil. Agric. Ecosyst. Environ. 113, 284-294.

Pei, S.F., Fu, H., Wan, C.G., Chen, Y.M., Sosebee, R.E., 2006. Observations on changes in soil properties in grazed and nongrazed areas of Alxa desert steppe, Inner Mongolia. Arid Land Res. Manag. 20, 161-175.

Piñeiro, G., Paruelo, J.M., Jobbagy, E.G., Jackson, R.B., Oesterheld, M., 2009. Grazing effects on belowground $\mathrm{C}$ and $\mathrm{N}$ stocks along a network of cattle exclosures in temperate and subtropical grasslands of South America. Global Biogeochem. Cycles 23.

Piñeiro, G., Paruelo, J.M., Oesterheld, M., Jobbagy, E.G., 2010. Pathways of grazing effects on soil organic carbon and nitrogen. Rangel Ecol. Manag. 63, 109-119.

Piao, S.L., Fang, J.Y., He, J.S., Xiao, Y., 2004. Spatial distribution of grassland biomass in China. Acta Phytoecol. Sin. 28, 491-498.

Piao, S.L., Fang, J.Y., Ciais, P., Peylin, P., Huang, Y., Sitch, S., Wang, T., 2009. The carbon balance of terrestrial ecosystems in China. Nature 458, U1009-U1082.

Proulx, M., Mazumder, A., 1998. Reversal of grazing impact on plant species richness in nutrient-poor vs nutrient-rich ecosystems. Ecology 79, 2581-2592.

Pucheta, E., Bonamici, I., Cabido, M., Diaz, S., 2004. Below-ground biomass and productivity of a grazed site and a neighbouring ungrazed exclosure in a grassland in central Argentina. Austral Ecol. 29, 201-208.

Raiesi, F., Asadi, E., 2006. Soil microbial activity and litter turnover in native grazed and ungrazed rangelands in a semiarid ecosystem. Biol. Fertil. Soils 43, 76-82.

Reeder, J.D., Schuman, G.E., 2002. Influence of livestock grazing on C sequestration in semi-arid mixed-grass and short-grass rangelands. Environ. Pollut. 116, 457-463.

Reeder, J.D., Schuman, G.E., Morgan, J.A., Lecain, D.R., 2004. Response of organic and inorganic carbon and nitrogen to long-term grazing of the shortgrass steppe. Environ. Manag. 33, 485-495.

Ren, J.Q., Cui, X.L., Zhao, B.B., 2008. Effects of grazing impact on community structure and productivity in an alpine meadow. Acta Pratacult. Sin. 17, $134-140$

Rosenberg, M.S., Adams, D.C., Gurevitch, J., 2000. Metawin Statistical Software for Meta-Analysis. Sinauer Associates, Sunderland, MA.

Schuman, G.E., Reeder, J.D., Manley, J.T., Hart, R.H., Manley, W.A., 1999. Impact of grazing management on the carbon and nitrogen balance of a mixed-grass rangeland. Ecol. Appl. 9, 65-71.

Scurlock, J.M.O., Hall, D.O., 1998. The global carbon sink: a grassland perspective. Global Change Biol. 4, 229-233.

Shaltout, K.H., ElHalawany, E.F., ElKady, H.F., 1996. Consequences of protection from grazing on diversity and abundance of the coastal lowland vegetation in Eastern Saudi Arabia. Biodivers. Conserv. 5, 27-36.

Shang, Z.H., Ma, Y.S., Long, R.J., Ding, L.M., 2008. Effects offencing, artificial seedling and abandonment on vegetation composition and dynamics of 'black soil land in the headwaters of the Yangtze and the Yellow rivers if the Qinghai-Tibetan Plateau. Land Degrad. Dev. 19, 554-563.

Shi, F.S., Chen, H., Wu, Y., Wu, N., 2010. Effects of livestock exclusion on vegetation and soil properties under two topographic habitats in an alpine meadow on the eastern Qinghai-Tibetan Plateau. Pol. J. Ecol. 58, 125-133.

Shirato, Y., Zhang, T.H., Ohkuro, T., Fujiwara, H., Taniyama, I., 2005. Changes in topographical features and soil properties after exclosure combined with sand-fixing measures in Horqin Sandy Land, Northern China. Soil Sci. Plant Nutr. 51, 61-68.

Shrestha, G., Stahl, P.D., 2008. Carbon accumulation and storage in semi-arid sagebrush steppe: effects of long-term grazing exclusion. Agric. Ecosyst. Environ. 125, 173-181.

Smith, R., Shiel, R., Millward, D., Corkhill, P., 2000. The interactive effects of management on the productivity and plant community structure of an upland meadow: an 8-year field trial. J. Appl. Ecol. 37, 1029-1043.

Snyman, H.A., du Preez, C.C., 2005. Rangeland degradation in a semi-arid South Africa - II: influence on soil quality. J. Arid Environ. 60, 483-507.

Song, Y.B., Yu, F.H., Keser, L., Dawson, W., Fischer, M., Dong, M., van Kleunen, M. 2012. United we stand, divided we fall: a meta-analysis of experiments on clonal integration and its relationship to invasiveness. Oecologia 171, 317-327.

Song, X.Z., Peng, C.H., Zhou, G.M., Jiang, H., Wang, W.F., 2014. Chinese Grain for Green Program led to highly increased soil organic carbon levels: a meta-analysis. Sci. Rep. 4, 528-528.

St Clair, S.B., Sudderth, E.A., Fischer, M.L., Torn, M.S., Stuart, S.A., Salve, R., Eggett, D.L., Ackerly, D.D., 2009. Soil drying and nitrogen availability modulate carbon and water exchange over a range of annual precipitation totals and grassland vegetation types. Global Change Biol. 15, 3018-3030.
Sternberg, M., Gutman, M., Perevolotsky, A., Ungar, E.D., Kigel, J., 2000. Vegetation response to grazing management in a Mediterranean herbaceous community: a functional group approach. J. Appl. Ecol. 37, 224-237.

Su, Y.Z., Li, Y.L., Cui, H.Y., Zhao, W.Z., 2005. Influences of continuous grazing and livestock exclusion on soil properties in a degraded sandy grassland, Inner Mongolia, northern China. Catena 59, 267-278.

Tanentzap, A.J., Coomes, D.A., 2012. Carbon storage in terrestrial ecosystems: do browsing and grazing herbivores matter? Biol. Rev. 87, 72-94.

van Kleunen, M., Weber, E., Fischer, M., 2010. A meta-analysis of trait differences between invasive and non-invasive plant species. Ecol. Lett. 13, 235-245.

Ward, S.E., Bardgett, R.D., McNamara, N.P., Adamson, J.K., Ostle, N.J., 2007. Long-term consequences of grazing and burning on northern peatland carbon dynamics. Ecosystems 10, 1069-1083.

Watkinson, A.R., Ormerod, S.J., 2001. Grasslands, grazing and biodiversity: editors' introduction. J. Appl. Ecol. 38, 233-237.

Werth, M., Brauckmann, H.J., Broll, G., Schreiber, K.F., 2005. Analysis and simulation of soil organic-carbon stocks in grassland ecosystems in SW Germany. J. Plant Nutri. Soil Sci. 168, 472-482.

Wienhold, B.J., Hendrickson, J.R., Karn, J.F., 2001. Pasture management influences on soil properties in the Northern Great Plains. J. Soil Water Conserv. 56, 27-31.

Wiesmeier, M., Steffens, M., Kolbl, A., Kogel-Knabner, I., 2009. Degradation and small-scale spatial homogenization of topsoils in intensively-grazed steppes of Northern China. Soil Tillage Res. 104, 299-310.

Wu, L., He, N.P., Wang, Y., Han, X., 2008. Storage and dynamics of carbon and nitrogen in soil after grazing exclusion in Leymus chinensis grasslands of northern China. J. Environ. Qual. 37, 663-668.

Wu, G.L., Du, G.Z., Liu, Z.H., Thirgood, S., 2009. Effect of fencing and grazing on a Kobresia-dominated meadow in the Qinghai-Tibetan Plateau. Plant Soil 319, $115-126$.

Wu, G.L., Liu, Z.H., Zhang, L., Chen, J.M., Hu, T.M., 2010. Long-term fencing improved soil properties and soil organic carbon storage in an alpine swamp meadow of western China. Plant Soil 332, 331-337.

Wu, Z.T., Dijkstra, P., Koch, G.W., Penuelas, J., Hungate, B.A., 2011. Responses of terrestrial ecosystems to temperature and precipitation change: a meta-analysis of experimental manipulation. Global Change Biol. 17, 927-942.

Wu, J.S., Zhang, X.Z., Shen, Z.X., Shi, P.L., Yu, C.Q., Song, M.H., Li, X.J., 2012. Species richness and diversity of alpine grasslands on the northern Tibetan Plateau: effects of grazing exclusion and growing season precipitation. J. Resour. Ecol. 3 , 236-242.

Wu, J.S., Zhang, X.Z., Shen, Z.X., Shi, P.L., Yu, C.Q., Chen, B.X., 2014. Effects of livestock exclusion and climate change on aboveground biomass accumulation in alpine pastures across the Northern Tibetan Plateau. Chin. Sci. Bull. 59, 4332-4340

Wu, X., Li, Z.S., Fu, B.J., Zhou, W.M., Liu, H.F., Liu, G.H., 2014. Restoration of ecosystem carbon and nitrogen storage and microbial biomass after grazing exclusion in semi-arid grasslands of Inner Mongolia. Ecol. Eng. 73, 395-403.

Xie, Y., Wittig, R., 2004. The impact of grazing intensity on soil characteristics of Stipa grandis and Stipa bungeana steppe in northern China (autonomous region of Ningxia). Acta Oecol. 25, 197-204.

Xie, Z.B., Zhu, J.G., Liu, G., Cadisch, G., Hasegawa, T., Chen, C.M., Sun, H.F., Tang, H.Y., Zeng, Q., 2007. Soil organic carbon stocks in China and changes from 1980 to 2000. Global Change Biol. 13, 1989-2007.

Xiong, D.P., Shi, P.L., Sun, Y.L., Wu, J.S., Zhang, X.Z., 2014. Effects of grazing exclusion on plant productivity and soil carbon, nitrogen storage in Alpine Meadows in northern Tibet, China. Chin. Geogr. Sci. 24, 488-498.

Xu, Z.R., Cheng, S.K., Zhen, L., Pan, Y., Zhang, X.Z., Wu, J.X., Zou, X.P., Bijaya, G.C.D., 2013. Impacts of dung combustion on the carbon cycle of alpine grassland of the north Tibetan plateau. Environ. Manag. 52, 441-449.

Yang, Y.H., Fang, J.Y., Ma, W.H., Smith, P., Mohammat, A., Wang, S.P., Wang, W., 2010. Soil carbon stock and its changes in northern China's grasslands from 1980 to 2000. Global Change Biol. 16, 3036-3047.

Zhao, H.L., Zhou, R.L., Su, Y.Z., Zhang, H., Zhao, L.Y., Drake, S., 2007. Shrub facilitation of desert land restoration in the Horqin Sand Land of Inner Mongolia. Ecol. Eng. 31, 1-8.

Zhao, L.P., Su, J.S., Wu, G.L., Gillet, F., 2011. Long-term effects of grazing exclusion on aboveground and belowground plant species diversity in a steppe of the Loess Plateau, China. Plant Ecol. Evol. 144, 313-320.

Zhou, Z.Y., Sun, O.J., Huang, J., Li, L., Liu, P., Han, X., 2007. Soil carbon and nitrogen stores and storage potential as affected by land-use in an agro-pastoral ecotone of northern China. Biogeochemistry 82, 127-138.

Zhu, X.P., Jia, H.T., Jiang, P.A., Zhao, C.Y., Hu, Y.K., Cao, Y.F., 2012. Effects of enclosure on plant diversity and community characteristics in pasture of Middle Tianshan Mountain. Pratacult. Sci. 29, 989-992. 